\title{
INVENTARIO DE RECUERDOS FICTICIOS
}

\begin{abstract}
Juan Gabriel Vásquez
En sus ficciones —advierte J. G. Vásquez en estas páginasMario Vargas Llosa se ha esforzado sobre todo en la creación de mundos autónomos cuya realidad se apodere de la mente del lector. El resultado es que sus novelas no sólo se han vuelto clásicos en toda regla; además nos han dejado una multitud de escenas intensamente vívidas que forman parte de nuestro imaginario de lectores pero también de nuestras vidas personales, escenas que recordamos como si nos hubieran ocurrido. Este ensayo escoge cuatro de esas escenas de cuatro de las novelas más importantes de Vargas Llosa — La ciudad y los perros, La casa verde, La guerra del fin del mundo e Historia de Mayta - y las analiza para descubrir cómo operan, qué las hace tan memorables y cuáles son su lugar y sus implicaciones en la obra entera de Vargas Llosa.
\end{abstract}

JuAN GABRIEl VÁsQUEz (Bogotá, 1973). Es autor de la colección de relatos Los amantes de Todos los Santos, de las novelas Los informantes, Historia secreta de Costaguana y El ruido de las cosas al caer, ganadora del Premio Alfaguara 2011. También ha publicado una recopilación de ensayos literarios, El arte de la distorsión (que incluye el ensayo ganador del Premio Simón Bolívar en 2007), y una breve biografía de Joseph Conrad, El hombre de ninguna parte. Ha traducido obras de John Hersey, John Dos Passos, Victor Hugo y E. M. Forster, entre otros, y es columnista del periódico colombiano El Espectador. Vive desde 1999 en Barcelona. 


\section{A manera de prólogo}

E

último realista: así lo llamaba Carlos Barral, así lo siguieron llamando muchos. Vargas Llosa, por supuesto, recogió la etiqueta y se la pegó con orgullo en la solapa, porque eso es lo que había sido siempre, porque se había hecho como novelista leyendo a Victor Hugo y a Flaubert, a Balzac y a Tolstoi y un poco a Hemingway y mucho a Malraux. A su alrededor, en esos mágicos años del boom, la gran literatura latinoamericana se dedicaba minuciosamente a distorsionar la realidad material o a negar francamente sus postulados físicos, a llevar hasta el límite los recursos de la fantasía o las libertades recreadoras del novelista: así García Márquez, así Borges y Cortázar, así el Rulfo de Pedro Páramo, así el Fuentes de Días enmascarados primero y de Terra Nostra después. Vargas Llosa, mientras tanto, se empeñaba en universos de novela realista decimonónica y los pasaba por el tamiz formal del modernismo, sin privarse de ningún hallazgo técnico, sin negar a sus libros el legado de los grandes renovadores del siglo XX, de Joyce a Faulkner.

Así que sepámoslo desde el principio: Vargas Llosa es un realista.

Y los escritores realistas en general (y Vargas Llosa en particular) suelen hacer en sus novelas lo mismo que admiran como lectores: la creación de mundos autónomos que parecen vivirse, no leerse; acciones y movimientos y escenarios que parecen suceder ante nuestros ojos, no en el lenguaje, sino más allá de él. Decía Hemingway que al describir un paisaje quería que el lector se quedara con la memoria del paisaje y no con las palabras usadas para describirlo. Esa ambición - la invención de experiencias que se quedan en la memoria del lector con tanta intensidad como si las hubiera vivido, y que en los mejores casos se convierten en parte de nuestro pasado con la misma nitidez que nuestros propios recuerdos - baña las grandes novelas de Vargas Llosa. Todos tenemos, entre nuestras memorias personales, esas memorias ajenas que nos han inoculado las grandes ficciones: imágenes que nos persiguen, detalles que se aparecen en el ojo de nuestra mente. Yo puedo ver, por ejemplo, el pequeño bolso y las hilachas que cuelgan de la manga de un vestido de mujer, y esa mujer es Ana Karenina y está a punto de tirarse a las vías del tren. Puedo sentir, por ejemplo, la presión de las agujas de pino en mi piel y luego recordar que la piel no es la mía, sino la de Robert Jordan, acostado en una colina española durante la guerra de 1936. 
Veo la tuza de mazorca con que Popeye viola a Temple Drake. Veo la mano que sale de un fiacre y tira a una calle francesa los trozos de un papel.

Cuando pienso en la obra de Vargas Llosa veo otras cosas, siento otras cosas. Lo que sigue es un inventario (más o menos razonado) de esos momentos que ocupan mi memoria con el mismo derecho que los que yo he vivido.

\section{Un telegrama en pedazos: La ciudad y los perros ${ }^{1}$}

El 2 de julio de 1962, Julio Cortázar escribe a Joaquín Díez Canedo sobre la novela que acaba de leer en manuscrito. Su autor, Mario Vargas, es un joven peruano que acaba de ganar un premio con un libro de cuentos. Escribe Cortázar: "Radicado en París, Vargas ha terminado hace poco la novela en cuestión, que se titula Los impostores. Admirablemente escrita, cuenta la vida de un grupo de estudiantes limeños en un colegio militar. Es un libro de una violencia, de una fuerza nada común en nuestros países. Un libro exasperado, por así decirlo". Meses más tarde, cuando la novela acaba de salir finalista del premio Formentor, Cortázar escribe a Vargas Llosa lamentándose de que le hayan hurtado el reconocimiento con malas artes, y todavía en esa carta sigue usando el título provisional en lugar del definitivo. Para los lectores de Vargas Llosa, las palabras La ciudad y los perros son un automatismo, como recitar nuestra dirección de juventud, pero lo cierto es que el título descartado hubiera podido muy bien servir de cara a una novela cuya riqueza (en situaciones, en estilos) no esconde su monotemática obsesión con las máscaras, los dobleces, las falsas identidades, los fingimientos. Nadie en La ciudad y los perros es quien dice ser: ni los estudiantes del Leoncio Prado, varios de los cuales tienen un apelativo para el colegio (el Poeta, el Esclavo) y otro para la ciudad (Alberto, Ricardo), ni los militares, cuyo código de honor no suele coincidir con sus prácticas. Uno de esos militares es el teniente Gamboa. En las novelas de Vargas Llosa suele haber un personaje que representa el poder; otro, con mayor o menor éxito (casi siempre con menor), representa la rebeldía ante el poder. Gamboa es un caso curioso: es el poder ante el cual se rebelan los estudiantes; simultáneamente, es el rebelde —aunque lo

\footnotetext{
${ }^{1}$ Páginas 451 a 459 (Alfaguara, 1997).
} 
sea malgré lui- ante el poder de sus superiores. Pero la suya es una rebeldía curiosa, que consiste en ser ciegamente fiel a la ética de cartón piedra que ha aprendido en su oficio y en sufrir por eso. "Trata de ser consecuente, coherente, y surge entonces una contradicción terrible", le dijo Vargas Llosa a Luis Harss hacia 1966. "Justamente para ser coherente y consecuente con ese sistema necesita violarlo, perjudicarse él mismo. No se rebela. Acepta". En la aceptación está la rebeldía.

Así se entiende la primera escena del epílogo, ocho páginas contenidas que se abren a verdades más amplias, a mundos más lejanos. (Las escenas de La ciudad y los perros son así, contenidas e intensamente visibles, construidas sobre la sugestiva precisión de los diálogos y el buen ojo para el detalle, un poco a la manera de La condición humana, de Malraux). Gamboa ha pagado cara su fidelidad al honor militar, o a su idea del honor militar: ha llevado la investigación por la muerte de Ricardo Arana más lejos de lo que hubieran querido sus superiores y, como sanción por sus varias osadías, por haber desafiado la jerarquía y por haber violado la regla principal de la vida militar —el egoísmo, el cinismo, el perro come perro-, ha sido trasladado del colegio Leoncio Prado de Lima a una guarnición en la puna, alejada del mundo civilizado (sic). Cuando se abre la escena, Gamboa ha entrado a despedirse de su capitán: ya ha pasado a ver al coronel, al comandante y al mayor, los superiores que determinaron su suerte (o arruinaron su carrera), y en ello hay como un susurro de la humillación que sufre Gamboa, obligado a mostrar respeto y hasta un confuso afecto a quienes lo han dañado. De ahí en adelante, no hay detalle de la escena que no sugiera algo. Un cadete está fuera de clase: Gamboa se preocupa, pregunta por qué, a pesar de que la vida de colegio y su rol disciplinario han concluido hace rato. "Es casi un vicio", dice. Y entonces Gamboa le pide al capitán que le dé permiso de salir a un cadete. "Necesito hablar con él a solas, en la calle", dice. "Es un asunto personal". "Ya veo —dice el capitán-. ¿Va usted a pegarle?".

Todo está ahí: la violencia de la novela entera, el poder que tienen unos sobre otros y la manera fácil y banal en que lo ejercen. "No sé", dice Gamboa. "A lo mejor". El cadete en cuestión es el Jaguar; y no, Gamboa no le pega. Pero antes de salir a su encuentro, Gamboa recibe de un teniente de servicios un telegrama que le acaba de llegar. "Lo abrió y lo leyó rápidamente", nos cuenta el narrador. "Luego lo guardó en el bolsillo". El narrador, fiel a una costumbre que ha adquirido en el 
curso de la novela, nos hurta el contenido del telegrama, que no provoca una reacción demasiado notoria: Gamboa se sienta en una banca y se queda inmóvil, con la mirada perdida. “¿Malas noticias?”, le preguntan. "No", contesta él. "Cosas de familia". Y luego sale a ver al Jaguar.

Caminan por la avenida Costanera, "por la tierra aplanada, al borde del abismo", y se detienen sólo cuando han perdido de vista el colegio. Ese abismo no es una metáfora fácil, sino esa cualidad que tienen los escenarios para conspirar en la creación de un sentido cuando la novela es observada cuidadosamente; la distancia que toman Gamboa y el Jaguar, en cambio, es uno de esos rasgos psicológicos que los primeros críticos de la novela no supieron ver. Allí, en la ciudad, lejos del mundo de los perros, hay otra vida: sí, es la realidad de la cual el Leoncio Prado es un modelo a escala, pero también se vive con menos intensidad, o en ella se permiten cosas que adentro son prohibidas. Y allí el Jaguar le entrega al teniente Gamboa el segundo papel de la escena. “¿Por qué ha escrito esto?", pregunta Gamboa. Los lectores no sabemos (aunque intuimos) qué es "esto". El Jaguar nos regala entonces su ética personal, su particular mode d'emploi: "Yo no le tengo miedo a nadie, mi teniente, sépalo usted", dice. "Se morían de miedo de que los bautizaran, temblaban como mujeres y yo les enseñé a ser hombres". Y luego viene la confesión: él mató a Ricardo Arana. Desprecia a sus compañeros de clase, que lo creen un soplón; la ingratitud lo enferma; no le importa aparecer ante ellos como un asesino; a Alberto, que lo había delatado, lo respeta porque, aunque soplón, lo que hizo lo hizo por vengar a un amigo. "No me interesan sus ideas sobre la lealtad y la venganza", le dice Gamboa. Y sin embargo el Jaguar sigue exponiéndolas, y de repente las tablas se han cambiado: es él el poderoso, el que tiene autoridad sobre la vida y la muerte de otro ser humano: él ha decidido que Arana era un individuo dañino y que tenía que eliminarlo, liberar a los demás (sus hijos, como si dijéramos) de su influencia. Son palabras de una crueldad inusitada, más crueles aún por la facilidad con que son pronunciadas.

El Jaguar cree que lo mejor será que vaya a la cárcel, tal como siempre se lo advirtió su madre (que no sabía, sin embargo, de las acusaciones de determinismo que pesarían sobre La ciudad y los perros), pero Gamboa no está dispuesto ni siquiera a llevarlo donde el coronel. "El caso Arana está liquidado”, le dice. Le pregunta entonces: “¿Sabe usted lo que son los objetivos inútiles?" Y luego: "Ni en la guerra debe haber muertos inútiles. Usted me entiende, vaya al colegio y trate en el futuro de que la muerte del cadete Arana sirva para algo". El párrafo 
cae con la carga de la resignación más intensa: en él está la decepción de Gamboa, la vida que deja atrás y lo que esa vida le ha hecho. No es por nada que la siguiente línea sea el momento en que Gamboa rasga el papel que le habían dado y lo arroja al suelo. Cuando se ha ido, en lo que es uno de los grandes momentos de esta novela, el Jaguar se agacha, recoge los pedazos y descubre el contenido del telegrama, una epifanía joyceana en toda regla, un boquete minúsculo por el cual entra una bocanada de luz a la ficción, una súbita transformación del personaje de Gamboa que modifica de paso todo lo que hemos leído hasta ahora, insertando en la rígida dualidad de la ciudad y el colegio un tercer elemento perturbador: la vida privada. La inusitada, imprevista, casi inefable vida privada. $\mathrm{Y}$ todo eso en trece palabras:

Hace dos horas nació niña. Rosa está muy bien. Felicidades. Va carta. Andrés.

\section{Un indio colgado de un árbol: La casa verde ${ }^{2}$}

Novela de violencias diversas, catálogo de la crueldad humana, La casa verde contiene más de una escena desgarradora; $\mathrm{y}$, cosa curiosa tratándose de una novela hecha sobre todo de diálogos, esas escenas tienen un misterioso poderío sobre la mente del lector, o por lo menos del lector que soy yo: la historia de Anselmo y la ciega y las conversaciones en el río de Fushía y Aquilino se me han aparecido más de una vez, y no siempre durante el sueño. Pero la que mejor recuerdo - la que mejor veo cuando cierro los ojos - ocurre sólo durante un breve momento del final de un libro: el gobernador Julio Reátegui acaba de salir del despacho de la madre superiora en Santa María de Nieva, donde ha estado discutiendo con ella el destino de una de las niñas indígenas que ha traído a la Misión para civilizarlas (y donde ha estado escuchando los horrendos gritos que llegan desde la plaza, una voz que grita de dolor y la otra que grita de ira y que vocifera y que insulta). Reátegui cruza el patio de la Misión y se encuentra al aire libre y empieza a caminar hacia la Gobernación. Y entonces escribe Vargas Llosa:

Al llegar a la plaza mira a Jum: las manos atadas sobre la cabeza, cuelga como una plomada de las capironas y entre sus pies suspendidos en el vacío y las cabezas de los mirones hay

${ }^{2}$ Páginas 379 a 383 de la primera edición (Seix Barral, 1966). 
un metro de luz. Benzas, Águila, Escabino ya no están allí, sólo el cabo Roberto Delgado, unos soldados, y aguarunas viejos y jóvenes reunidos en grupo compacto. El cabo ya no vocifera, Jum está callado también. Julio Reátegui observa el embarcadero: las lanchas se balancean vacías, ya terminaron de descargar. El sol es crudo, vertical, de un amarillo casi blanco. Reátegui da unos pasos hacia la Gobernación, pero al pasar ante las capironas se detiene y vuelve a mirar. Sus dos manos prolongan la visera del casco y aun así los rayos agresivos hincan sus ojos. Sólo se divisa su boca, ¿está desmayado?, que parece abierta, ¿lo ve a él?, ¿va a gritar peruanos otra vez?, ¿va a insultar de nuevo al cabo? No, no grita nada, a lo mejor tampoco tiene la boca abierta. La posición en que se halla ha sumido su estómago y alargado su cuerpo, se diría un hombre delgado y alto, no el pagano fortachón y ventrudo que es. Algo extraño transpira de él, así como está, quieto y aéreo, convertido por el sol en una esbelta forma incandescente.

En Historia secreta de una novela, el maravilloso ensayo sobre La casa verde que la editorial Tusquets publicó (con tinta verde) en 1971, Vargas Llosa cuenta los orígenes de ese libro formidable en términos que no dejan mucho espacio a la ambigüedad: "Escribir una novela es una ceremonia parecida al strip-tease", dice. "Como la muchacha que, bajo impúdicos reflectores, se libera de sus ropas y muestra, uno a uno, sus encantos secretos, el novelista desnuda también su intimidad en público a través de sus novelas". La intimidad, en Historia secreta de una novela, está hecha de memorias: las memorias que con el tiempo se convirtieron en La casa verde. Así sabemos los lectores de la versión original de esa casa, un prostíbulo del desierto piurano que ejercía una atracción sobre el niño Vargas Llosa; así sabemos de las visitas de Vargas Llosa a la selva peruana y de los encuentros reales que condujeron a los personajes ficticios; y por este último camino llegamos a saber de Jum, el alcalde aguaruna del pueblito de Urakusa, y del enfrentamiento con el gobernador Reátegui que termina con la tortura del indio. Confrontemos la versión que da el ensayo con la de la ficción. Jum es capturado por las autoridades junto con otros seis de su tribu. "Al día, siguiente", escribe Vargas Llosa,

Jum fue transportado, solo, a Santa María de Nieva. Lo colgaron de un árbol en la plaza, desnudo, y fue azotado hasta que perdió el conocimiento. Le quemaron las axilas con huevos calientes (nunca he podido entender cómo lo hicieron). A 
la tortura siguió la humillación: fue rapado. Presidieron el escarmiento el Teniente-gobernador de Santa María de Nieva, Julio Reátegui; el Juez de Paz, Arévalo Benzas; el alcalde, Manuel Águila; un teniente del Batallón de Ingenieros número 5, Ernesto Bohórquez Rojas, la maestra del lugar, Alicia de Reátegui, y un misionero jesuita. Luego de tres días de torturas Jum fue puesto en libertad y regresó a Urakusa.

De lo último no nos habla la novela, que yo recuerde: la historia de Jum acaba en La casa verde con su figura colgada en la plaza, "esa forma incandescente". Pero el lector se ha percatado sin duda de la verdadera singularidad, o más bien, de la singular correspondencia que hay entre el episodio real y el episodio de la ficción. Yo leí La casa verde en mayo de 1996 (en Bogotá) y leí Historia secreta de una novela un mes después (ya en París). Y recuerdo muy bien haberme tenido que parar del banco del Jardin des Plantes donde leía el ensayo al darme cuenta de que sí, de que mi memoria no me engañaba, de que Vargas Llosa había conservado en la novela los nombres de las personas reales (digamos históricas) que protagonizaron o perpetraron ese episodio real (digamos histórico). ¿Estaba permitido esto?, me pregunté en la inocencia de mis 23 años. Preguntas más interesantes: ¿habían leído la novela Reátegui, Benzas, Delgado? ¿La estarían quemando en este momento en algún rincón oculto de la selva peruana, tal como los militares habían quemado La ciudad y los perros? La novela no sólo recogía la tortura de Jum, sino que en el tejido de la ficción habían quedado para siempre inmortalizados los torturadores, y ahí siguen, a la vista de todos, denunciados para toda la eternidad, repitiendo sus acciones innobles hasta el final de los tiempos.

Hamlet le advertía al pobre Polonio que tratara bien a los actores, pues ellos son "la crónica de nuestro tiempo: más te valdrá tener un mal epitafio después de muerto que una mala reputación entre ellos mientras vivas".

Será a los novelistas que se refería.

\section{Unos dedos en la espalda: La guerra del fin del mundo ${ }^{3}$}

Vargas Llosa ha dicho que, sin embargo de los elaborados planes que suele dedicar a sus novelas, de sus fichas y sus trayectorias cuida-

${ }^{3}$ Páginas 450 a 457 (Biblioteca Ayacucho, 1991). 
dosamente trazadas y sus libretas de notas, llega un momento en que los personajes cobran vida propia y él, (no tan) sorprendido, no tiene más remedio que ponerse a seguirlos. Nabokov se burlaba de los novelistas para quienes los personajes se independizan y acaban haciendo lo que quieren: "Mis personajes son esclavos de galeras", decía. Pero en el universo del realismo $-\mathrm{y}$ ya lo hemos visto: no hay que olvidar que Vargas Llosa es, entre mucha otras cosas a veces contradictorias, un escritor realista - todo novelista sabe que eso es perfectamente posible: un personaje se niega a seguir siendo lo que el autor quería y comienza a ser otra cosa. Así el teniente Gamboa en La ciudad y los perros, según ha dicho o más bien confesado el propio Vargas Llosa. Y así el Barón de Cañabrava, protagonista de una escena extraordinaria en esta novela hecha de escenas extraordinarias, este inmenso aparato narrativo que comparte estantería con los grandes momentos de la novela decimonónica sin desmerecer en lo más mínimo: La guerra de fin del mundo. En un diálogo con Ricardo Setti, Vargas Llosa dice:

El caso del Barón de Cañabrava fue muy interesante para mí en La guerra del fin del mundo, porque era un personaje que había nacido un poco de una representación esquemática: él debía representar las fuerzas más retrógradas de la sociedad. Era un personaje cargado de negatividad. Sin embargo, yo creo que, al final, se descubre que es uno de los personajes más positivos de la novela, por lo menos en el sentido de que él cambia con la historia. Es decir, la historia, para él, es motivo de una profunda revisión interior, de todo su concepto de la sociedad, del mundo, de su propia manera de ser. Se produce una revisión extraordinaria. Es uno de los personajes que entienden, además, que allí [en Canudos] ha ocurrido algo muy importante, que pone en tela de juicio su propio mundo.

Es una disección acertada, por supuesto, pero demasiado fría para lo que termina con uno de los momentos más intensos, más conmovedores y a la vez inquietantes, más perturbadores y a la vez tiernos, que se hayan visto en la literatura latinoamericana. El Barón de Cañabrava entiende, sí: pero en ese verbo pacífico se oculta una profunda y dramática sacudida de todo su espacio vital, algo que va mucho más allá de la comprensión intelectual de un fenómeno histórico. Su legendaria hacienda de Calumbí ha sido quemada y arrasada por los rebeldes 
yagunzos; y esa desgracia — que no es simplemente económica- ha tenido consecuencias imprevisibles para el Barón: su esposa Estela, a quien ama con el amor desmedido y grandioso de los grandes personajes románticos, ha enloquecido (a la manera de los grandes personajes románticos). El Barón, dolido y apabullado por las circunstancias - diríamos: por la historia-, se retira de la vida pública, se niega a recibir visitas y, sobre todo, se niega a recordar. Aquí, como en tantas otras novelas de Vargas Llosa - Conversación en La Catedral, por ejemplo, o Historia de Mayta - , la memoria es incómoda: la memoria es el enemigo.

Pero entonces llega una visita que no estaba prevista: el periodista miope, dado por muerto mucho tiempo atrás, llega a la residencia del Barón con el propósito aparente de pedirle trabajo, y comienza para éste uno de los días más extraños y determinantes de su vida. El Barón no quiere recordar, pero el periodista recuerda por él; el Barón quiere escapar de la historia, del Ángel de la Historia, pero acepta escuchar la versión de los hechos de Canudos que le da el periodista, y el Ángel de la Historia se las arregla entonces para darle alcance. "Se están olvidando de Canudos", dice el periodista miope, genuinamente preocupado. El Barón responde: "Olvidémosla, es lo mejor. Es un episodio desgraciado, turbio, confuso. No sirve. La historia debe ser instructiva, ejemplar. En esa guerra nadie se cubrió de gloria. Ya nadie entiende lo que pasó". Y entonces el periodista hace esta promesa solemne: "No permitiré que se olviden". El Barón le pregunta cómo piensa evitar el olvido. "De la única manera que se conservan las cosas - dice el periodista-. Escribiéndolas".

Y durante largas horas se dedica a contarle al Barón lo que vio y lo que no vio, lo que descubrió leyendo periódicos en la Academia Histórica, lo que descubrió leyendo sus propios reportajes sobre los hechos de Canudos. Su relato -inverosímil, exagerado pero cierto, doloroso pero inescapable - hace una profunda mella en la conciencia del Barón. El espectáculo, para nosotros, es maravilloso: el Barón cambia a medida que habla y, sobre todo, que escucha. Y esa transformación tiene su consecuencia (su imprevisible consecuencia) al final de la larga conversación, cuando ya el periodista se ha ido y el Barón se queda solo: solo con su memoria, solo con las evocaciones del periodista miope, solo con su relato de amor y de muerte, solo con el pasado tormentoso de su país entero, solo con la historia, "tratando de alejar ese hervidero de confusas y violentas imágenes". Decidir su destino no parece costarle 
demasiado esfuerzo: "Había cortado con el mundo y no restablecería las amarras". ¿Pero por qué, entonces, esa sensación incómoda que se le ha instalado en las tripas? "Qué lo desasosegaba así?", se pregunta. “QQué le producía esa impaciencia, ese cosquilleo en el cuerpo, como si estuviera olvidando algo urgentísimo, como si en estos segundos fuera a ocurrir algo irrevocable y decisivo en su vida?" Tras unas imágenes de muerte y descomposición, en la mente del Barón de Cañabrava aterrizan unas palabras ajenas sobre el amor y el placer: "Lo más grande que hay en el mundo, Barón, lo único a través de lo cual puede encontrar el hombre cierta felicidad". Y es como si algo se adueñara de él.

Sube las escaleras y en segundos está entrando a la recámara de Sebastiana, la criada que ha dedicado su vida a cuidar de Estela. Se da cuenta de que durante demasiado tiempo ha renunciado al placer; se da cuenta de que su sexo empieza a despertar ante esa mujer que no es la suya. Sebastiana se resiste, trata de gritar y el Barón le tapa la boca con la mano. "La señora, la señora", logra susurrar ella bajo el peso del Barón. La escena es alucinada, en parte porque lo que ocurre es violento, una violación en toda regla, y sin embargo está bañado por una extraña cualidad que nos impide sentir la violencia como debe de sentirla Sebastiana. El Barón vence a la fuerza la resistencia de la mucama, que en ese momento es una más de sus propiedades y, al mismo tiempo y contradictoriamente, el objeto de un impulso vital no carente de nobleza. La besa en los senos, le quita el camisón y besa su vientre. Y entonces:

Con las manos, con la barbilla presionó con todas sus fuerzas, sintiendo que ella sollozaba, hasta hacerle separar los muslos lo suficiente como para poder llegar hasta su sexo con la boca. Cuando lo estaba besando, succionando suavemente, hundiéndole la lengua y sorbiendo sus jugos, sumido en una ebriedad que, por fin, lo liberaba de todo lo que lo entristecía y amargaba, de esas imágenes que le roían la vida, sintió la presión suave de unos dedos en la espalda. Apartó la cabeza y miró, sabiendo lo que iba a ver: ahí estaba Estela, de pie, mirándolo.

La brutal imagen cobra una brutalidad renovada por la conciencia de que Estela mira sin ver, de que no sabemos qué sucede en su enloquecida percepción del mundo. Pero me interesan sobre todo esas palabras sobre la libertad recuperada allí, en ese momento de sexo ilícito pero como perdonado o condonado por la mirada vacía de una 
mujer loca: allí, el Barón logra escapar por un instante del monstruo de la historia reciente. Con la cara metida entre las piernas de una mujer, con la mano de su esposa tocándole la cabeza, el Barón experimenta una rara reconciliación consigo mismo y con el mundo que le ha arruinado la vida. De la oscuridad del sexo de Sebastiana, la escena pasa a la luz del amanecer bahiano: y en esa mirada que el Barón echa por la ventana, en ese ataque de nostalgia que le trae a la memoria a sus compañeros políticos, hay una tensión insoportable, la tensión de dos mundos, de los dos hombres: uno echado a perder por la vida pública, otro pugnando por vivir su vida privada. Entonces el Barón se fija en el puerto pesquero donde los pescadores no están trabajando, sino rezando y bailando. Ahí, en esa singular imagen vista desde la lejanía y a través de los prismáticos de su mujer loca, el Barón ve todo lo que hasta ahora no había visto: el cambio profundo que se ha operado en su sociedad, su tierra, su mundo.

En Vargas Llosa el sexo (más o menos libre, más o menos violento, más o menos consentido) es muchas veces agente de cambios feroces: basta pensar en el Anselmo de La casa verde, en el padre de Zavalita en Conversación en La Catedral, en la Urania de La fiesta del Chivo. Pero en estas páginas de La guerra del fin del mundo confluyen como no lo hacen en ninguna otra parte de su obra: en una habitación de Salvador se chocan la vida más íntima y la historia más pública. Y, como siempre, del choque no quedan más que ruinas.

\section{Un rebelde vendiendo helados: Historia de Mayta $^{4}$}

Ah, la pobre Historia de Mayta. Se habla de Vargas Llosa como de un clásico vivo, se hacen inventarios de sus enormes ficciones - que definieron una época, que moldearon una idea de Latinoamérica, de lo que es ser un novelista, de lo que es ser un novelista de Latinoamérica-, se menciona indefectiblemente esa suerte de trilogía involuntaria que va del Leoncio Prado a La Catedral pasando por la selva y el desierto, se acude luego a la novela brasileña y a la novela dominicana $\mathrm{y}$, según el hablante, se mencionarán las dos maravillas del humor que fueron la novela de las putas amazónicas y aquella otra de la tía y la radio. Pero Historia de Mayta, por alguna razón, se ha convertido

\footnotetext{
${ }^{4}$ Páginas 309 a 356 de la primera edición (Seix Barral, 1984).
} 
(bien, seamos sinceros: lo fue desde el principio) en el patito feo de la biblioteca de Vargas Llosa. Y sin embargo yo tengo para mí que se trata de una de las novelas más logradas de esa biblioteca y un miembro con derecho en cualquier hipotética lista de clásicos latinoamericanos.

Magistral en su arquitectura, poderosa en su argumento, implacable en su voluntad aguafiestas y osada en su borroneo de las fronteras entre ficción y realidad, Historia de Mayta hizo hace veintisiete años lo que hasta hace meses se saludaba como el último grito de la vanguardia literaria. Cuando Javier Cercas escribió la maravillosa Soldados de Salamina y cobró notoriedad inesperada por el uso de un narrador llamado Javier Cercas, que vive la vida de Javier Cercas, investiga en la vida de un hombre que le es ajeno y al hacerlo investiga en la vida política y moral de su país, España, los críticos o los lectores hubieran podido recordar Historia de Mayta, esta novela en que un narrador que para todos los efectos es Mario Vargas Llosa vive la vida de Mario Vargas Llosa e investiga en la vida de un hombre que le es ajeno y al hacerlo investiga en la vida política y moral de su país, Perú. Pero no lo hicieron: no recordaron a Mayta. Por razones políticas, o politizados en sus raciocinios, los lectores - sobre todo los latinoamericanos - de Historia de Mayta llevaban ya varios años relegando el libro al olvido o imponiéndole un destierro de la República vargasllosiana, y era lógico entonces que nadie le atribuyera a Vargas Llosa el ascendiente sobre varios de los más interesantes proyectos literarios que se hacen hoy en lengua española. Es igual: Historia de Mayta sobresale hoy en día como una de las reflexiones más penetrantes e intensas y despiadadas que se hayan escrito sobre la relación entre la ficción y los hechos, sobre la falibilidad de la memoria privada, sobre los engaños de la memoria pública y, a fin de cuentas, sobre las incertidumbres de ese gran monstruo incierto que llamamos historia. Y todo eso está en la última escena del libro, una maravilla sin par en la literatura latinoamericana.

Ustedes recuerdan que Historia de Mayta está construida alrededor de las pesquisas de un escritor peruano: sus visitas a los testigos de un momento del pasado - un conato de revolución socialista en la población de Jauja - y, a través de lo que esos testigos cuentan, la reconstrucción de ese momento. En el último capítulo, Vargas Llosa (el hombre que hace las veces de Vargas Llosa) llega al clímax de la investigación: encuentra a Alejandro Mayta, el protagonista del incidente de marras, y le pide una entrevista. “ ¿Me asusta la idea de enfrentarme por 
fin con el personaje sobre el que he estado investigando, interrogando a la gente, fantaseando y escribiendo hace un año?", se pregunta antes de verlo. Durante ese tiempo se ha obsesionado con Mayta (su obsesión prefigura para mí la de Nathan Zuckerman en American Pastoral, una de las obras maestras de Philip Roth), pero se ha topado con el muro del pasado: "Es sumamente difícil reconstruir su historia", dice, porque "no hay casi documentación sobre los hechos en los que fue acusado de intervenir, ni testigos que quieran abrir la boca". La iluminación de un espacio oscuro del pasado es una de las tareas más nobles de ese aparato que llamamos novela: eso es lo que hace Historia de Mayta. Aunque lo haga a través de la imaginación, de la ficción y por lo tanto de la fabricación y de la mentira. Cuando Vargas Llosa o "Vargas Llosa" encuentra por fin a Mayta, le explica que ha estado escribiendo una novela sobre él. Pero le aclara:

En una novela siempre hay más mentiras que verdades, una novela no es nunca una historia fiel. Esa investigación, esas entrevistas, no eran para contar lo que pasó realmente en Jauja, sino, más bien, para mentir sabiendo sobre qué mentía.

"Mentir con conocimiento de causa", ha dicho Vargas Llosa en otras partes. Así es: Historia de Mayta, como tantas otras grandes novelas, es metaliteraria aun a pesar de sí misma, un artefacto que trae consigo - disimulado, camuflado - su propio manual de instrucciones. "Caramba", dice Mayta. "Esto sí que es lo último que se me hubiera ocurrido. ¿Una novela?" Vargas Llosa se apresura a vindicar de nuevo los privilegios de la ficción, en parte como caveat emptor, en parte para tranquilizar a Mayta: llega incluso a asegurarle que su nombre ha cambiado en la ficción. Mayta, sin embargo, se ve molesto; pero lo que lo molesta no es la aterradora perspectiva de verse metido en las páginas de un libro ajeno, sino que el autor de ese libro parece saber más de su vida que él mismo. "Me molesta porque me doy cuenta que usted está mejor informado que yo", dice. "Sí, no es broma. Se me han olvidado muchas cosas y otras las tengo confusas. Quisiera echarle una mano y contarle. Pero el problema es que ya no sé muy bien todo lo que pasó, ni cómo pasó. Hace mucho de todo eso, dese cuenta".

Una de las grandes revelaciones de la conversación es ésta: el incidente que ha obsesionado a Vargas Llosa, que le ha quitado el sueño durante un año, que lo ha obligado a recrearlo en la soledad de su 
estudio y mediante las herramientas de la ficción, para Mayta es apenas uno entre muchos, y desde luego no el más importante. "No sabe usted qué raro me resulta hablar de política, recordar hechos políticos", dice Mayta. "Es como un fantasma que volviera, desde el fondo del tiempo, a mostrarme cosas olvidadas". La tensión entre el olvido y la memoria baña la escena, pero en estas líneas sale a flote y nos salta a la cara: Mayta, que en las páginas de la novela ha sido un revolucionario idealista y entusiasta, en este último capítulo, reducido por la vida a empleado de una heladería, ni siquiera conserva un recuerdo claro de las acciones que definieron su vida (que para Vargas Llosa definieron su vida). Es un hombre sin identidad. En "Una épica de la transgresión", su extraordinario ensayo sobre la obra entera de Vargas Llosa, Alonso Cueto escribe:

Pero la rebelión es una relación, es decir una forma de la dependencia. Si el destino del hijo es el de rebelarse contra el padre, debe organizar su vida en función de esa rebeldía. Cercado por la realidad del padre, ningún hijo puede ignorarla y por lo tanto liberarse de su impugnación. La rebeldía es una identidad que los reduce y abarca. Los rebeldes dependen enteramente de su lucha y una vez desaparecido el motivo de ésta, deben renunciar a su ser. Están sostenidos por el padre contra el que se rebelan. Para que ellos sigan existiendo, su rebeldía está condenada a ser permanente.

Muertos los padres, los rebeldes han perdido su identidad. La mayor parte de los conspiradores dominicanos son asesinados. Zavalita escribe editoriales en un periodicucho de la Avenida Tacna; Mayta tiene un puesto de vendedor de helados. El paradójico drama del rebelde es que no tiene una identidad fuera de su lucha con el poderoso. Depende del poderoso para negarlo y para afirmarse. Su destino no es vencerlo sino hundirse con él.

Así Alejandro Mayta, hundido en el marasmo del olvido, humillado por las murallas infranqueables de su propia condición. Su fracaso, por supuesto, es el del Perú, el de la historia peruana: la gran Historia del país se topa con la pequeña historia del individuo.

Al final de la novela, el narrador Vargas Llosa mira a Mayta y piensa: "También tú, como tantos otros, sólo piensas ahora en escapar antes que nos hundamos del todo".

Pero no escapará. Nadie escapa en la obra de Vargas Llosa. 
"El pasado no está muerto, ni siquiera ha pasado", dice Faulkner en Réquiem por una monja.

En Historia de Mayta, eso es más cierto que nunca.

\section{A manera de coda}

Hay otras escenas que guardo en mi memoria, que vuelven a mí mientras escribo o mientras leo (no necesariamente a Vargas Llosa) y sobre todo mientras no hago ni lo uno ni lo otro, mientras compro el pan o espero en la fila del banco o llego en bus a algún sitio de Barcelona o miro la oscuridad previa al sueño. Primer ejemplo: la escena del mitin reventado en Conversación en La Catedral, ese prodigio de orquestación y detalle donde los lectores vemos a Ludovico y a Ambrosio hablando en un hospital ("Es una historia que no hay por donde contarla, porque todo son mentiras", dice Ludovico como si fuera el coro de la obra entera de Vargas Llosa), sentimos las granadas que estallan en el teatro, oímos las vivas a Odría y olemos el aire que se remueve con la violencia, con los palazos y las patadas y los empujones y los gritos de miedo, y compartimos también el soroche de Trifulcio, tan real como el cinismo de don Fermín y la preocupación de Cayo Bermúdez. Segundo ejemplo: la escena de las duchas en Los cachorros, con ese sonsonete casi caricaturesco que da un tinte raro a la desgracia de un alumno a punto de ser castrado por el mordisco de un perro - "A veces ellos se duchaban también, guau, pero ese día, guau guau, cuando Judas se apareció en la puerta de los camarines, guau guau guau, sólo Lalo y Cuéllar se estaban bañando"- - y luego, claro, viene el ataque, "los ladridos de Judas, el llanto de Cuéllar, los gritos". Tercer ejemplo: la escena en la Clínica Internacional, donde Pedro Livio — alias el Negro — yace desangrándose en una camilla tras haber participado en el atentado a Trujillo y haber recibido un balazo en el vientre, y mira el mundo y oye a quienes lo rodean a través de la bruma y del dolor, ese mundo alucinado en el cual aparece su esposa embarazada ("Está muerto, Olga, muerto", le dice, refiriéndose al odiado dictador) y aparecen también los médicos que le tratan de salvar la vida, que lo mueven sin que él sienta nada. Y luego, finalmente, aparece el coronel Johnny Abbes García y empieza a hacer preguntas sobre la conspiración y a usar diversos medios para conseguir las respuestas: "La mano del coronel se elevó, cogió el ciga- 
rrillo encendido de su boca y, sin cambiar de expresión, lo aplastó contra su cara, cerca de su ojo izquierdo. Pedro Livio no gritó, no gimió. Cerró los párpados. El ardor era vivo; olía a carne chamuscada".

Yo recuerdo ese olor. Yo estaba allí. Yo recuerdo los gritos de Cuéllar y el ambiente tenso del teatro Metropolitano. Y recuerdo que comencé este ensayo hablando del Vargas Llosa realista, o del realismo como poética de sus novelas. $\mathrm{Y}$ ahora recuerdo también algo que el escritor colombiano Ricardo Cano Gaviria le dijo a Vargas Llosa: "Si todo es realidad, si la irrealidad, como decías, también forma parte de la realidad, eso quiere decir, ni más ni menos, que todos los escritores son realistas". Vargas Llosa responde:

Creo que la única división que se puede establecer a este respecto es que hay literatura que tiene vida, y literatura que carece de vida... La primera es "realista", la segunda "irreal". Puesto que la realidad a la que se refiere la novela es una realidad puramente humana, no una realidad natural ni una realidad divina, si una novela carece de vida, si no representa nada dentro de los valores humanos, su autor sí puede ser llamado "irreal". No es "irreal" Borges, cuentista, pero Corín Tellado sí es "irreal".

Y entonces otros recuerdos me asaltan: un almacén del sur donde unos borrachos tiran migas de pan a un convaleciente; un sótano de Buenos Aires donde una esfera guarda o refleja o contiene todo lo que hay en el mundo; una habitación de hotel donde alguien ha dejado, en una máquina de escribir, una página con ocho palabras misteriosas: $L a$ primera letra del nombre ha sido articulada.

Seguro que Vargas Llosa recuerda esas cosas también.

\section{REFERENCIAS}

Cueto, Alfonso. "Una épica de la transgresión". En Mario Vargas Llosa: La libertad y la vida. Lima: Planeta Perú, 2008.

Setti, Ricardo. Sobre la vida y la política: Diálogo con Vargas Llosa. México:

Kosmos Editorial, 1990.

Vargas Llosa, Mario. La ciudad y los perros [1963] Alfaguara, 1997.

L La casa verde. Seix Barral, 1966.

- La guerra del fin del mundo [1981]. Biblioteca Ayacucho, 1991.

- Historia de Mayta. Seix Barral, 1984. 